\title{
Cross-cultural adaptation, validity and reliability of the Turkish version of Revised Nonverbal Pain Scale
}

\author{
Revize Sözel Olmayan Ağrı Ölçeği'nin Türkçe versiyonunun kültürlerarası uyarlaması, \\ geçerliği ve güvenirliği
}

(1) PInar KAYA, ${ }^{1}$ (D) Sevilay ERDEN ${ }^{2}$

\begin{abstract}
Summary
Objectives: In this study, we aimed to adapt the Revised Nonverbal Pain Scale (NVPS-R) into Turkish, and to test reliability and validity of the scale.

Methods: A total of 74 patients who were admitted to eight intensive care units in two hospitals between May 2016 and August 2017 were included in this study. All patients were over 18 years old, mechanically ventilated, and sedated. The data were obtained $1 \mathrm{~min}$ before, during and $20 \mathrm{~min}$ after the aspiration using the NVPS-R-TR and Critical Care Pain Observation Tool (CPOT).

Results: Language, content, construct validity and reliability analyses were performed for the reliability and validity of the scale. Factor loadings in explanatory factor analysis were sufficient $(0.790-0.900)$, and the fit indices of the scale were acceptable values in confirmatory factor analysis ( $x^{2}$ SSD: 2.414, RMSEA: 0.066, CFI: 0.910, SRMR: 0.073, GFI: 0.950 and AGFI: 0.930). After internal consistency analyses of the scale, the item-total correlation was sufficient (0.604-0.794), and Cronbach's alpha score was 0.776.
\end{abstract}

Conclusion: NVPS-R-TR is a reliable and a valid measuring tool for the pain evaluation of sedated adults who are under mechanical ventilation in the intensive care unit.

Keywords: Intensive care; pain; pain assessment; reliability; validity.

\section{Özet}

Amaç: Bu çalışmada Revize Sözel Olmayan Ağrı Ölçeği'nin (NVPS-R) Türkçeye uyarlanması ve ölçeğin güvenirliği ve geçerliğinin test edilmesi amaçlandı.

Gereç ve Yöntem: Çalışmaya Mayıs 2016-Ağustos 2017 tarihleri arasında iki hastanede sekiz yoğun bakım ünitesine alınan toplam 74 hasta dahil edildi. Hastaların tümü 18 yaşın üzerinde, mekanik ventilasyon desteği alan ve sedasyonlu hastalardı. Veriler NVPS-R-TR ve Kritik Bakım Ağrı Gözlem Aracı (CPOT) kullanılarak aspirasyondan 1 dk. önce, aspirasyon sırasında ve aspirasyondan $20 \mathrm{dk}$. sonra toplandı.

Bulgular: Ölçeğin güvenirliği ve geçerliği için dil, içerik, yapı geçerliği ve güvenirlik analizleri yapıldı. Açıklayıcı faktör analizindeki faktör yüklemeleri yeterli bulundu $(0.790-0.900)$ ve ölçeğin uyum indeksleri doğrulayıcı faktör analizinde kabul edilebilir değerlerde idi ( $\mathrm{x}^{2}$ /SD: 2.414, RMSEA: 0.066, CFI: 0.910, SRMR: 0.073, GFI: 0.950 ve AGFI: 0.930). Iç tutarlılık analizlerinden sonra, 0.776 Cronbach alfa skoru ile madde-toplam puan korelasyonu yeterli düzeyde bulundu (0.604-0.794).

Sonuç: NVPS-R-TR, yoğun bakım ünitesinde mekanik ventilasyon desteği verilen sedasyonlu erişkinlerin ağrı değerlendirmesinde güvenilir ve geçerli bir değerlendirme aracıdır.

Anahtar sözcükler: Yoğun bakım; ağrl; ağrı değerlendirmesi; güvenirlik; geçerlik.

'Department of General Surgery Intensive Care, Adana City Hospital, Adana, Turkey

${ }^{2}$ Department of Nursing, Cukurova University Faculty of Health Science, Adana, Turkey

Submitted (Başvuru tarihi) 07.02.2018 Accepted after revision (Düzeltme sonrası kabul tarihi) 09.10.2018 Available online date (Online yayımlanma tarihi) 02.11.2018

Correspondence: Dr. Sevilay Erden. Çukurova Üniversitesi Sağlık Bilimleri Fakültesi, Hemşirelik Bölümü, Sarı̧am, Adana, Turkey.

Phone: +90 - 322 - 3386484 / 1134 e-mail: sevilaygil@gmail.com

() 2019 Turkish Society of Algology 


\section{Introduction}

A total of 30 to $40 \%$ of the patients in the intensive care unit (ICU) experience pain and $87 \%$ of the pain is in moderate and severe intensity. ${ }^{[1,2]}$ In an intensive care patient who has impaired hemodynamic parameters or who carries a risk of hemodynamic deterioration at any time, medical status can worsen by increasing the stress response; therefore, it should necessarily be controlled..$^{[3,4]}$ The first and the most important step in pain control is a thorough evaluation of pain. The most reliable source in pain evaluation is the patient himself. However, the intensive care patient who is intubated, sedated, or with impaired consciousness is unable to express his/her pain, as he/she is not able to have verbal communication. Therefore, pain which is a subjective condition, should be turned to an objective state so far as possible in intensive care patients in whom communication is difficult. ${ }^{[5]}$

Pain identification scales were developed in which the behavioral and behavioral-physiological signs of pain are scored in particularly sedated and mechanically ventilated patients. Among these scales, the most commonly used scales are Behavioral Pain Scale (BPS), Critical Care Pain Observation Tool (CPOT), and Nonverbal Pain Scale (NVPS). ${ }^{[5-7]}$ In the BPS and CPOT, the severity of pain is measured by the evaluation of the patient behaviorally and the patient's adaptation to mechanical ventilation. Although the NVPS enables evaluation of physiological parameters together with behavioral responses, it offers a more comprehensive measurement opportunity compared to others. Thus, intensive care pain guidelines state that, in addition to subjective observations (e.g., facial expressions, body posture, motion), physiological markers can be also used as pain-related behavior in non-communicating patients and these guidelines recommend pain evaluation according to these alterations. ${ }^{[8-11]}$

The NVPS, which was first developed in 2003 by Odhner et al., ${ }^{[12]}$ was revised in 2009 by Kabes et al. ${ }^{[10]}$ (NVPS-R). The scale was originally recommended to be used in patients who were unable to provide verbal communication in burn, trauma, and intensive care units. In 2017, Chookalayi et al. ${ }^{[1]}$ reported that both the original and the revised forms of the scale was valid and reliable in intensive care patients who were on mechanical ventilation. However, the "respiration" section could be more sensitively measured in the revised scale.

Both the relevant studies in the literature and our experience demonstrate that pain evaluation practice of nurses in intensive care is inadequate, despite the existing scales. Esen et al. ${ }^{[13]}$ reported that pain was not holistically evaluated in intensive care, whereas Kizza and Muliira ${ }^{[9]}$ found that pain evaluation practice of intensive care nurses was not sufficient. Eti Aslan et al.'s ${ }^{[14]}$ study also showed that $39.6 \%$ of the intensive care nurses did not know pain evaluation, and only $22 \%$ of them used a pain scale. Although previous studies suggest that there is a lack of pain evaluation, these results can be improved using an appropriate and simple pain evaluation scale. Topolovec et al.'s ${ }^{[15]}$ study revealed that nurses used the NVPS-R easily in non-communicating and sedated patients, and the self-confidence of the nurses in the pain evaluation improved and the frequency of pain evaluation and their registry increased in the patients.

Determination of validity and reliability of the pain scales used in sedated and mechanical ventilation, the closest scale to our culture, would enable health care team to evaluate pain easily. Therefore, in the present study, we aimed to adapt the NVPS-R into Turkish (NVPS-R-TR) and to test reliability and validity of the scale.

\section{Materials and Methods}

This methodological study was conducted between May 2016 and August 2017 in two hospitals in Turkey, including a university hospital and an education and training hospital. The universe of the research was formed by the third-level institutions in Adana. This study was conducted in the intensive care units of surgery, cardiovascular surgery, neurosurgery, and anesthesiology departments.

A total of 74 patients aged above 18 who were treated in the intensive care units and who were sedated and under mechanical ventilation were included in this study. Patients' relatives gave their consent for this study. The patients who were using paralytic drugs, who had quadriplegia and brain death were excluded. For the calculation of the sample size, the Number Cruncher Statistical System (NCSS)-Power 
Analysis and Sample Size System (PASS) 2008 program were used. Based on the study performed by Kabes et al.'s study ${ }^{[10]}$ in 2009, according to this calculation to achieve power of 0.90 , significance level of $.05,74$ participants were needed for the study.

Data were collected using the Personal Data Form, Ramsay Sedation Scale (RSS), NVPS-R-TR, and CPOT. The RSS was used for the determination of sedation level of patients, which were explained below. The consistency of NVPS-R-TR in time was analyzed by parallel form method and CPOT form was used.

Personal Information Form: This form consists of seven questions on the sociodemographic (age, sex, marital status) and clinical characteristics of the patients (treatment department, indications for hospitalization, chronic illness, and duration of hospitalization).

RSS was designed by Ramsay et al. ${ }^{[16]}$ in 1974 to assess the level of consciousness. Sedation level is scored between 1 and 6 . The depth of sedation increases as the score increases.

CPOT was developed in Canada by Gelinas et al. ${ }^{[17]}$ in 2006 and its Turkish validity and reliability were performed in 2016 by Gundogan et al. ${ }^{[18]}$ The CPOT is composed of four subsections which evaluate behavioral characteristics. Each section is scored between 0 and 2 , and the total score is between 0 and 8 .

NVPS was first developed in 2003 by Odhner et al. ${ }^{[12]}$ and revised by Kabes et al. ${ }^{[10]}$ in 2009. In the present study, the Turkish form (NVPS-R-TR) of the revised scale (NVPS-R) was used following Kabes et al. ${ }^{[10]}$ The scale is composed of five sections. Each section is scored between $0-2$ and total score changes between $0-10$. In the interpretation of the scale, $0-2$ shows no pain, 3-6 shows mild pain, and 7-10 shows severe pain.

Procedures: The pain scores of the intensive care patients who met the criteria of the sample were obtained during aspiration procedure in which the pain was the most severe. ${ }^{[13,19]}$ The investigator scored the pain intensity by observing the patients $1 \mathrm{~min}$ before the aspiration, during aspiration and $20 \mathrm{~min}$ after the aspiration. The pain scores of the patients were determined using both NVPS-R-TR and CPOT.

\section{Statistical analysis}

Statistical analysis was performed using the NCSS and PASS 2008 software (NCSS, LLC, Kaysville, UT, USA). Descriptive data were expressed in mean \pm standard deviation (SD) and number ( $\mathrm{n}$ ) and percentage (\%). The content validity of the questionnaire was evaluated through the opinions of specialists. For the construct validity, the Barlett test, the KaiserMeyer-Olkin (KMO) Index, the exploratory factor analysis and the confirmatory factor analysis were performed, which are detailed below. As part of the reliability analysis, the Cronbach's a coefficient and Pearson's product-moment correlation coefficient were used to determine the internal consistency and homogeneity.

\section{Ethical considerations}

The permission for adaptation of NVPS-R to Turkish was obtained from Anne Maria Kabes (E-mail date: 24.02.2017) who revised the scale and put it into use, as we were unable to reach Margaret Odhner who developed the scale. Ethical approval was obtained from the Non-interventional Clinical Investigations Ethical Committee of Cukurova University, Medical Faculty (Decision number: 55; Date: 04.03.2017), and a written permission was obtained from Cukurova University, Medical Faculty, Balcalı Hospital (No: 45868485-044) and Adana Local Health Authority (No: 69937107/010.99). Furthermore, a verbal and written consent were obtained from the relatives of the patients.

\section{Results}

In this study, a total of 74 patients were included. The mean age was $53.65 \pm 16.77$ (median 52) years. The mean duration of hospital stay was $11.728 \pm 8.5$ ( median 5). A total of $62.2 \%$ of the patients were hospitalized in the intensive care unit of cardiovascular surgery, while $95.9 \%$ were hospitalized due to surgical treatment.

\section{Findings on the validity of the NVPS-R-TR Linguistic and cultural validity}

The NVPS-R was translated from English into Turkish by six different translators to identify the equivalence of concepts and map the concepts to the target culture. After examination of the Turkish items by the investigator, a common form was developed, and these forms were retranslated into 
English by six translators who are fluent in both English and Turkish. The retranslated English form and the original form were sent to Anne Maria Kabes by an e-mail. When the response "there is no change in meaning" (Personal communication, Anne Maria Kabes-24.02.2016) was taken, the retranslated Turkish form was used.

\section{Content validity}

The Turkish scale which met the language validity and the original scale was delivered to nine specialist academicians. The specialists' opinions were taken by an e-mail, or printed form and the specialists examined the items of the scale regarding its clearness and cultural convenience. The specialists were asked to assess each item between 1 and 5; as 1-never convenient, 2-not convenient, 3-partially convenient, 4-convenient and 5-most convenient. The result of the content validity criterion/content validity index was 1.00. As the content validity of the questionnaire was found to be statistically significant, none of the items was excluded from the questionnaire.

\section{Construct validity}

The KMO index was used to determine whether the sample size was adequate for factor analysis, and Bartlett's test of sphericity was used to evaluate the appropriateness of factor analysis and to determine whether the variables were correlated with each other. The KMO index was 0.739 and Barlett's test was $X^{2}=105.433$, and $p<0.001$. The significance of this test showed that the sample size was adequate for factor analysis and that the correlation matrix was appropriate.

\section{Factor analysis}

The factor structure of the scale was assessed by both Exploratory Factor Analysis (EFA) and Confirmatory Factor Analysis (CFA).

\section{Exploratory factor analysis}

The EFA aims to decrease the number of variables and to reveal new structures from the relation between the variables. As the factor load of the items of NVPSR-TR was above 0.60 (between 0.790 and 0.900 ) items were not removed from the scale (Table 1 ).

The eigenvalue is the sum of squares of factor loads of each factor and as this value increases the variance that the factor explains also increases. It was found that the eigenvalue of the first two items of
Table 1. Items and factor loadings

\begin{tabular}{lc}
\hline Item & Factor loading \\
\hline 1. Face & 0.854 \\
2. Activity & 0.833 \\
3. Guarding & 0.790 \\
4. Physiological-1 & 0.900 \\
5. Respiratory & 0.891 \\
\hline
\end{tabular}

Table 2. Total variance explained of the NVPS-R-TR

\begin{tabular}{lccc}
\hline \multicolumn{3}{l}{ Total variance explained } \\
\hline Component & \multicolumn{3}{c}{ Eigenvalues } \\
\cline { 2 - 4 } & Total & Variance \% & Cumulative \% \\
\hline 1 & 2.089 & 41.774 & 41.774 \\
2 & 1.702 & 34.047 & 75.822 \\
3 & 0.485 & 9.695 & 85.517 \\
4 & 0.395 & 7.894 & 93.411 \\
5 & 0.329 & 6.589 & 100.000 \\
\hline
\end{tabular}

NVPS-R: Revised Nonverbal Pain Scale. Basic principal component analysis.

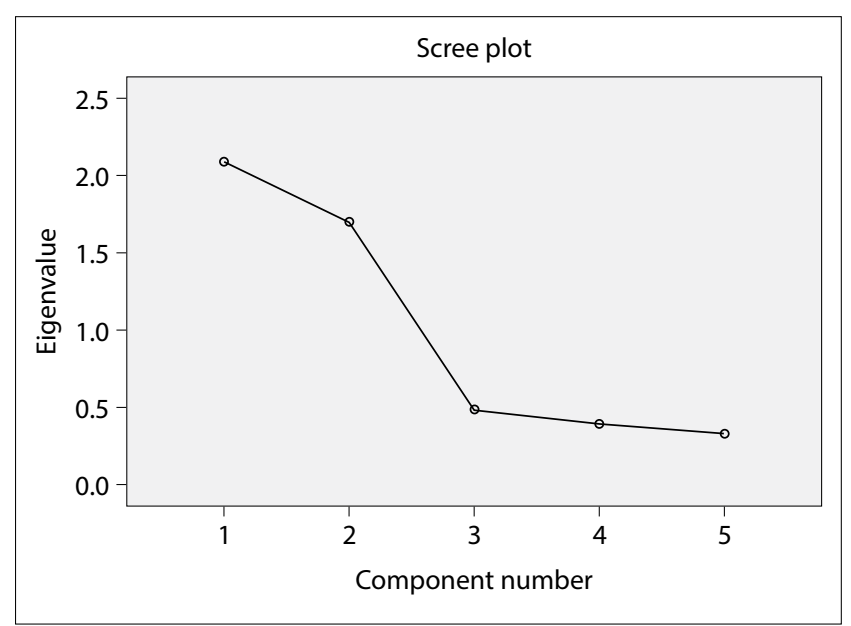

Figure 1. Eigenvalue scree plot showing factor structure.

the scale was above 1 and they contributed to total variance at a rate of $75.822 \%$ (Table 2). The scree plot related to the factor structure of the scale is presented in Figure 1.

\section{Confirmatory factor analysis}

Fit indices in structural equation modeling do not have a single significant statistic defining the correct model to the given sample data. As for rating the model compatibility in confirmatory factor analysis and the structural equation model, fit indices were 
Table 3. Fit index values for the NVPS-R-TR: The normal and acceptable values

\begin{tabular}{lccc}
\hline Index* & $\begin{array}{c}\text { Values } \\
\text { found }\end{array}$ & $\begin{array}{c}\text { Normal } \\
\text { value }\end{array}$ & $\begin{array}{c}\text { Acceptable } \\
\text { value }\end{array}$ \\
\hline$\chi^{2} / S D$ & 2.414 & $<2$ & $<5$ \\
RMSEA & 0.066 & $<0.05$ & $<0.08$ \\
CFI & 0.910 & $>0.95$ & $>0.90$ \\
SRMR & 0.073 & $<0.05$ & $<0.08$ \\
GFI & 0.950 & $>0.95$ & $>0.90$ \\
AGFI & 0.930 & $>0.95$ & $>0.90$ \\
\hline
\end{tabular}

NVPS-R: Revised Nonverbal Pain Scale; *AGFI: Adjusted goodness of fit index; CFI: Comparative fit index; GFI: Goodness of fit index; RMSEA: Root mean square error of approximation; SD: standard deviation; SRMR: Standardized root mean square residual.

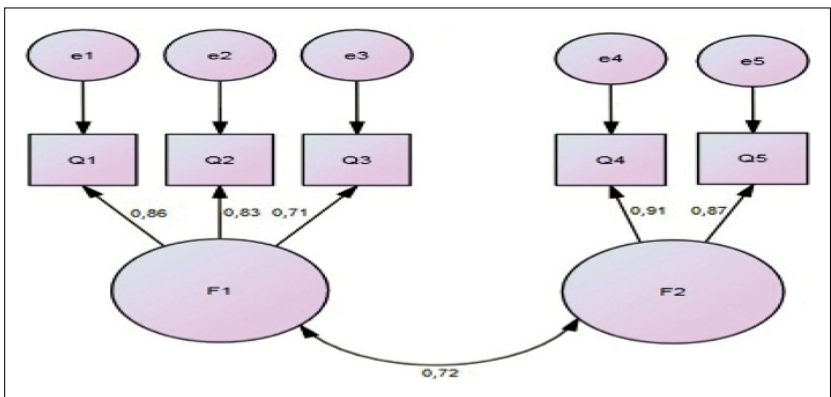

Figure 2. The path diagram for the Revised Nonverbal Pain Scale Turkish version.

classified as fit indices based on residuals, independent model, root mean square error of approximation (RMSEA), data criterion, and those based on relation criteria. While analyzing model fits, $x^{2} / S D$ was discussed together with fit indices based on residual (SRMR, GFI, AGFI), fit index based on independent model (CFI), and root mean square error of approximation (RMSEA).

In four-point model adaptation of the scale, $x^{2} / S D$ was found as 2.414, RMSEA as 0.066, CFI as 0.910, SRMR as $0.073, \mathrm{GFI}$ as 0.950 and $\mathrm{AGFI}$ as 0.930 . These index
Table 4. Parallel forms equivalence results

\begin{tabular}{cccc}
\hline Variable & \multicolumn{3}{c}{ NVPS-R-TR } \\
\hline $\begin{array}{c}\mathbf{1} \text { min } \\
\text { before } \\
\text { aspiration }\end{array}$ & $\begin{array}{c}\text { During } \\
\text { aspiration }\end{array}$ & $\begin{array}{c}\mathbf{2 0 ~} \mathbf{m i n} \\
\text { after } \\
\text { aspiration }\end{array}$ \\
\hline CPOT & 0.887 & 0.967 & 0.930 \\
$p$ & $\mathbf{p}<\mathbf{0 . 0 0 1}$ & $\mathbf{p}<\mathbf{0 . 0 0 1}$ & $\mathbf{p}<\mathbf{0 . 0 0 1}$ \\
\hline
\end{tabular}

NVPS-R: Revised Nonverbal Pain Scale.

values indicated that the NVPS-R-TR was at an acceptable level and consisted of two subscales (Table 3 ).

The PATH diagram was used in the presentation of the direct and indirect relations between the variables. The factor structure related to NVPS-R-TR items which was obtained as a result of CFI is presented as PATH diagram (Fig. 2).

Findings on the reliability of the NVPS-R-TR Findings of correlation between the NVPS-R-TR and the CPOT

The consistency of the scale was determined with the Pearson correlation coefficient method using parallel form (CPOT). Positive and high correlations were observed between NVPS-R-TR and the CPOT at all times (Table 4).

\section{Internal consistency}

The Cronbach's a coefficient is frequently used in the scale development and adaptation studies to determine the internal consistency reliability with an aim to reveal the consistency level of the items in the scale with each other. Total values of the items, total correlation of the items and Cronbach alpha values in which the items were deleted are presented in Table 5.

Table 5. Total item correlations and Cronbach's a coefficients of the questionnaire

\begin{tabular}{lcccc}
\hline Items (n=74) & Mean & $\begin{array}{c}\text { Standard } \\
\text { deviation }\end{array}$ & $\begin{array}{c}\text { Total item } \\
\text { correlation }\end{array}$ & $\begin{array}{c}\text { Cronbach's a value } \\
\text { when the item is deleted }\end{array}$ \\
\hline Face & 1.35 & 0.63 & 0.794 & 0.765 \\
Activity & 0.98 & 0.73 & 0.660 & 0.679 \\
Guarding & 1.42 & 0.57 & 0.746 & 0.623 \\
Physiological-1 & 0.98 & 0.77 & 0.604 & 0.733 \\
Respiratory & 0.71 & 0.72 & 0.645 & 0.697
\end{tabular}

Cronbach- $\mathrm{a}=0.776$. 


\section{Discussion}

In the literature, several scales were developed to be used in the evaluation of pain in adult intensive care patients and their validity and reliability were tested. However, there is a limited number of studies related to the psycholinguistic and psychometric analysis of NVPS-R which has been developed to be used in mechanically ventilated and sedated intensive care patients. Psycholinguistic measurement has been conducted in Finnish and psycholinguistic and psychometric measurements have been done in Persian, in Dutch, in Korean and English, but neither psycholinguistic nor psychometric measurements have been performed in Turkish previously. ${ }^{[6,10,20,21]}$ To contribute to this gap in the literature, our study indicated that the NVPS-R-TR was acceptable pain evaluation scale for Turkish mechanically ventilated and sedated adult patients.

In the present study, the validity of the structure was examined to determine whether all items of the scale measure the pain of the sedated patient in the intensive care unit or not. KMO coefficient for structure validity of NVPS-R-TR was 0.739 , and the sample size was found to be very well sufficient. According to Bartlett's test analysis, data were based on the multivariate normal distribution, and the NVPS-R-TR was convenient for factor analysis $(p<0.001)$. In previous studies which were performed in other languages, factor analysis results related to the structure validity were not observed.

The fact that whether the items in NVPS-R-TR is summed up under different structures or not, has been evaluated. As the factor load of the items of NVPS-R-TR was found between 0.790 and 0.900 (Table 1), any item was not removed from the scale. As reported in Figure 1, the eigenvalue of the first two items in the scale was above 1, and these two items contributed to total variance at a rate of $75.822 \%$. It could be seen that the rapid accelerated decrease of NVPS-R-TR in scree plot was reduced after the 3rd point (Fig. 1). Each distance between two points means a factor. In accordance with data obtained from scree plot graph together with the eigenvalue and variance percentages, the scale was found to be convenient to the two-factor structure.

The CFA is applied to investigate the factor structure of the nursing scale. ${ }^{[22]}$ There is no consensus related to which adaptation indices for CFA would be accepted as standard. ${ }^{[22]}$ It has been found that five-point model adaptation index values of the scale have acceptable values ( $x^{2} / S D$ value 2.414 , RMSEA 0.066 , CFI 0.910, SRMR 0.073, GFI 0.950 and AGFI 0.930) (Table 3). Although the adaptation index values of NVPSR-TR were not reported in the study of TopolovecVranic et al., ${ }^{[21]}$ it was found that discriminant validity value which gives information about CFA is sufficient. Two-factor structure of NVPS-R-TR which was found with EFA has been demonstrated with CFA as a figure in the PATH diagram. It is necessary for factor loads to be above 0.30 in CFA. It has been found that factor loads of the items of the scale change between 0.71 and 0.91 as a result of CFA, thus factor loads were found to be at the excellent level (Fig. 2).

According to the factor analysis results presented above, the face, activity and protection items in the NVPS-R-TR constituted the first factor, and vital signs and respiratory parameters constituted the second factor. This result can be explained as the first factor represents behavioral symptoms and the second factor represents physiological findings.

The clinical condition of the critical patient in the intensive care unit varies, and this situation causes fluctuations in pain intensity level. Thus, in the present study parallel form reliability method was used in the analysis of the consistency of the scale in time. For measurement of the reliability of NVPS-RTR, CPOT was used as the closest scale. The Pearson correlation value of the scales was found as $r=0.887$; $p<0.001$ before the practice, as $r=0.967 ; p<0.001$ during the practice and as $r=0.930 ; p<0.001$ after the practice. According to these findings, a positive correlation was found between NVPS-R-TR and CPOT, and this was highly statistically significant (Table 4). Similarly, in the scale reliability study of Marmo and Fowler, ${ }^{[23]}$ a high level of correlation was found between the NVPS-R-TR and CPOT $(r>0.80 ; p<0.001)$. In both the present study and previous studies, the NVPS-R-TR was found to be equivalent to the frequently used CPOT in unconscious, intubated and mechanically ventilated adult patients. ${ }^{[23,24]}$

The consistency of the NVPS-R-TR scale was measured in other validity and reliability studies which 
have been performed in French, Korean and Persian. ${ }^{[6,11,21]}$ In all of the studies, the consistency of the scale in time was found to be moderate and high. As a result, we suggest that both NVPS-R-TR and CPOT help to measure the severity of pain in mechanically ventilated, sedated patients by providing data based on the evaluation of facial and body movements, muscle strain and respiration.

The hypothesis that all subdimensions of NVPS-RTR could measure the same feature was determined by item-total correlation and Cronbach Coefficient Alpha analysis. In the present study, item-total correlation was found between 0.604 and 0.794 and the Cronbach alpha coefficient of the scale during aspiration was found as 0.776 . Thus, it is possible to report that all items in the scale measure the same concept (Table 5). The internal consistency value of the current study is similar to some previous studies in which both the original and the revised form of the scale have been used. Cronbach alpha value varies between 0.72 and 0.89 in the previous studies. ${ }^{[10,}$ ${ }^{11,23}$ In light of the findings in the present study and previous studies, it could be concluded that all items in NVPS-R-TR consistently measure pain in unconscious intensive care patients who could not express themselves verbally.

Sedation in intensive care unit could hide the symptoms of pain during pain evaluation in patients who were unable to express pain verbally. ${ }^{[8,25]}$ Thus, RSS was used to assess the sedation level of the patients in the present study. Although it has not been reported in the table, RSS score was 3.48 \pm 1.42 (median 4) and a statistically significant and weak negative correlation was found between RSS and CPOT ( $r=-$ $0.252, p=0.030)$ and RSS and NVPS-R-TR ( $r=-0.257$, $\mathrm{p}=0.027$ ) during practice. This condition gives rise to the thought that pain symptoms could be hidden due to suppression of sensorial and motor functions. In pain and sedation guidelines and in the previous intensive care studies, it is recommended to evaluate pain under daily intermittent sedation or mild levels of sedation. ${ }^{[26-28]}$ Within this context, it could be necessary to evaluate pain by the intermittent discontinuation of sedation in such a way that hemodynamic stability is not disturbed.

In conclusion, our study results suggest that the
NVPS-R-TR is a valid and reliable measurement tool for the pain evaluation of intubated and sedated intensive care patients who are unable to communicate verbally.

\section{Conflict-of-interest issues regarding the authorship or article: None declared.}

\section{Peer-rewiew: Externally peer-reviewed.}

\section{References}

1. Kotfis K, Zegan-Barańska M, Szydłowski Ł, Żukowski M, Ely EW. Methods of pain assessment in adult intensive care unit patients - Polish version of the CРOT (Critical Care Pain Observation Tool) and BPS (Behavioral Pain Scale). Anaesthesiol Intensive Ther 2017;49(1):66-72.

2. Puntillo KA, Morris AB, Thompson CL, Stanik-Hutt J, White CA, Wild LR. Pain behaviors observed during six common procedures: results from Thunder Project II. Crit Care Med 2004;32(2):421-7.

3. Eti-Aslan F. Ağrı Değerlendirme Yöntemleri. Cumhuriyet Üniveristesi Hemşirelik Yüksekokulu Dergisi 2002;6(1):916.

4. Puntillo K. Pain assessment and management in the critically ill: wizardry or science? Am J Crit Care 2003;12(4):310-6.

5. Yaman-AktaşY, Karabulut N. Mekanik ventilasyonlu hastada ağrı değerlendirmesi. Gümüşhane Üniversitesi Sağlık Bilimleri Dergisi 2014:3(4):1132-46.

6. Jung-Soon K, In-Soon K, Kyu-Hyun P. Reliability and validity of Nonverbal Pain Assessment Scale for patients who stayed a intensive care units. The Korean Journal of Health Service Management 2015;9(2):89-102.

7. Pudas-Tähkä SM, Axelin A, Aantaa R, Lund V, Salanterä S. Translation and cultural adaptation of an objective pain assessment tool for Finnish ICU patients. Scand J Caring Sci 2014;28(4):885-94.

8. Jablonski J, Gray J, Miano T, Redline G, Teufel H, Collins T, et al. Pain, Agitation, and Delirium Guidelines: Interprofessional Perspectives to Translate the Evidence. Dimens Crit Care Nurs 2017;36(3):164-73.

9. Kizza IB, Muliira JK. Nurses' pain assessment practices with critically ill adult patients. Int Nurs Rev 2015;62(4):573-82.

10. Kabes AM, Graves JK, Norris J. Further validation of the nonverbal pain scale in intensive care patients. Crit Care Nurse 2009;29(1):59-66.

11. Chookalayi $H$, Heidarzadeh $M$, Hasanpour $M$, Jabrailzadeh S, Sadeghpour F. A Study on the Psychometric Properties of Revised-nonverbal Pain Scale and Original-nonverbal Pain Scale in Iranian Nonverbal-ventilated Patients. Indian J Crit Care Med 2017;21(7):429-35.

12. Odhner M, Wegman D, Freeland N, Steinmetz A, Ingersoll $\mathrm{GL}$. Assessing pain control in nonverbal critically ill adults. Dimens Crit Care Nurs 2003;22(6):260-7.

13. Esen H, Öztürk ZK, Badır A, Aslan-Eti F. Entübe ve sedatize yoğun bakım hastalarının pozisyon verme ve aspirasyon sırasındaki ağrı davranışları. Acıbadem Üniversitesi Sağlık 
Bilimleri Dergisi 2010;1(2):89-93.

14. Eti-Aslan F, Badır A. The problem of pain in intensive care units: An issue of widespread interest but inadequate questioning. Journal of Intensive Care Nursing 2003;7(2):100108.

15. Topolovec-Vranic J, Canzian S, Innis J, Pollmann-Mudryj MA, McFarlan AW, Baker AJ. Patient satisfaction and documentation of pain assessments and management after implementing the adult nonverbal pain scale. Am J Crit Care 2010;19(4):345-54.

16. Ramsay MA, Savege TM, Simpson BR, Goodwin R. Controlled sedation with alphaxalone-alphadolone. $\mathrm{Br}$ Med J 1974;2(5920):656-9.

17. Gélinas C, Fillion L, Puntillo KA, Viens C, Fortier M. Validation of the critical-care pain observation tool in adult patients. Am J Crit Care 2006;15(4):420-7.

18. Gündoğan $O$, Bor C, Korhan EA, Demirağ K, Uyar M. Erişkin yoğun bakım hastasında ağrı değerlendirmesi: CriticalCare Pain Observation Tool Ölçeği'nin Türkçe versiyonunun geçerlik güvenirlik araştırması. Türk Yogun Bakim Dernegi Dergisi 2016;14(3):93-9.

19. Vatansever-Esen H. Cerrahi yoğun bakım ünitesinde mekanik ventilatöre bağlı hastalarda ağı davranışlarının incelenmesi. Marmara Üniversitesi Sağlık Bilimleri Enstitüsü 2016, Yükseklisans Tezi. İstanbul.

20. Pudas-Tähkä SM, Axelin A, Aantaa R, Lund V, Salanterä S. Pain assessment tools for unconscious or sedated intensive care patients: a systematic review. J Adv Nurs 2009;65(5):946-56.
21. Topolovec-Vranic J, Gelinas C, Li Y, Pollmann-Mudryj MA, Innis J, McFarlan A, et al. Validation and evaluation of two observational pain assessment tools in a trauma and neurosurgical intensive care unit. Pain Res Manag 2013;18(6):e107-14.

22. Çapık C. Geçerlik ve güvenirlik çalışmalarında doğrulayıcı faktör analizinin kullanımı. Anadolu Hemşirelik ve Sağlık Bilimleri Dergisi 2014;17(3):196-205.

23. Marmo L, Fowler S. Pain assessment tool in the critically ill post-open heart surgery patient population. Pain Manag Nurs 2010;11(3):134-40.

24. Wysocki A, Zucker D, Bigelow C. Acute pain symptom assessment and management in nonverbal puerto rican patients in the early postoperative period. University of Massachusetts Amherst Doctoral Dissertations 2016.

25. Çelik S. Yoğun Bakım Hastalarında Ağrı Yönetimi. Yoğun Bakım Hemşireliği Dergisi 2016;20(1):1-8.

26. Barr J, Fraser GL, Puntillo K, Ely EW, Gélinas C, Dasta JF, et al.; American College of Critical Care Medicine. Clinical practice guidelines for the management of pain, agitation, and delirium in adult patients in the intensive care unit. Crit Care Med 2013;41(1):263-306.

27. Garrett KM. Best Practices for Managing Pain, Sedation, and Delirium in the Mechanically Ventilated Patient. Crit Care Nurs Clin North Am 2016;28(4):437-50.

28. Nassar AP Junior, Park M. Sedation protocols versus daily sedation interruption: a systematic review and meta-analysis. [Article in English, Portuguese]. Rev Bras Ter Intensiva 2016;28(4):444-51. 